\title{
Spatial-temporal variability of Mytilus galloprovincialis Lamarck 1819 populations and their accumulated sediment in Northern Portugal
}

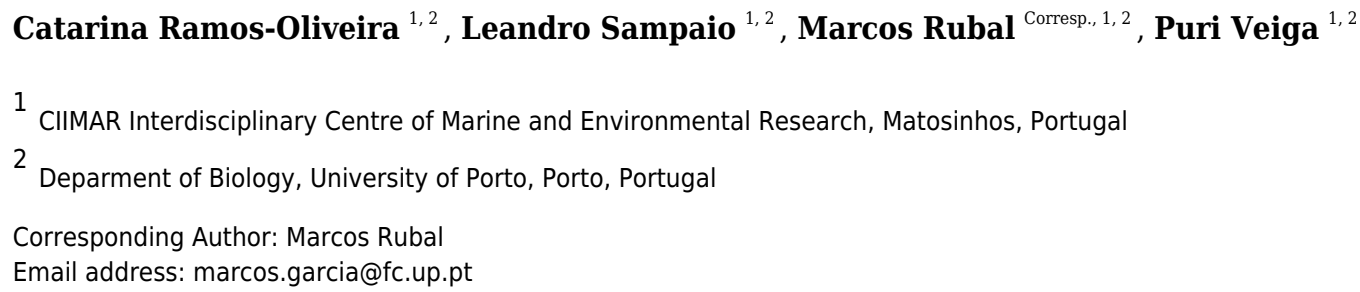

Mytilus galloprovincialis is an ecosystem engineer that provides habitat and generates environmental heterogeneity, increasing local biodiversity. Moreover, it is an economically important species representing $14 \%$ of the global production of marine bivalves. Natural drivers and the increase of anthropogenic pressures, such as sediment stress, influence its populations on rocky shores. The objective of this study was to explore the spatialtemporal patterns of different M. galloprovincialis attributes along North of Portugal. For that purpose, six rocky shores were selected and sampled six times along the year 2019. The percentage of cover, density, spat density, condition index, clump thickness, size classes and clump sediment content were considered. Results showed the lack of seasonality in M. galloprovincialis along the North coast of Portugal. However, density, spat stage, clump thickness, condition index and size classes showed some variability among dates and shores. The percentage cover and sediment content only significantly differed among shores. Our results indicated an absence of seasonality for all the studied variables, probably because temperature was always within the optimum range for this species and the abundance of food supply in the study area independently of the season. The accumulated sediment on mussel clumps did not show any temporal variability with only significant differences among shores. The accumulated sediment was composed mainly by medium and coarse sand and it was correlated with mussel average size, condition index, but especially with the mussel clump thickness. 


\section{Spatial-temporal variability of Mytilus galloprovincialis}

\section{Lamarck 1819 populations and their accumulated}

\section{4 sediment in Northern Portugal}

6

Catarina Ramos-Oliveira ${ }^{1,2}$, Leandro Sampaio ${ }^{1,2}$, Marcos Rubal $^{1,2 *}$, Puri Veiga ${ }^{1,2}$

${ }^{1}$ CIIMAR Interdisciplinary Centre of Marine and Environmental Research of the University of Porto, Novo Edifício do Terminal de Cruzeiros do Porto de Leixões, Avenida General Norton de Matos, Matosinhos, Portugal

${ }^{2}$ Department of Biology, Faculty of Sciences, University of Porto, Porto, Portugal Corresponding Author:

Marcos Rubal

Centre of Marine and Environmental Research of the University of Porto, Novo Edifício do Terminal de Cruzeiros do Porto de Leixões, Avenida General Norton de Matos S/N, 4450-208, Matosinhos, Portugal

Email address: marcos.garcia@fc.up.pt

\section{Abstract}

Mytilus galloprovincialis is an ecosystem engineer that provides habitat and generates

environmental heterogeneity, increasing local biodiversity. Moreover, it is an economically important species representing $14 \%$ of the global production of marine bivalves. Natural drivers and the increase of anthropogenic pressures, such as sediment stress, influence its populations on rocky shores. The objective of this study was to explore the spatial-temporal patterns of different M. galloprovincialis attributes along North of Portugal. For that purpose, six rocky shores were selected and sampled six times along the year 2019. The percentage of cover, density, spat density, condition index, clump thickness, size classes and clump sediment content were considered. Results showed the lack of seasonality in M. galloprovincialis along the North coast of Portugal. However, density, spat stage, clump thickness, condition index and size classes showed some variability among dates and shores. The percentage cover and sediment content only significantly differed among shores. Our results indicated an absence of seasonality for all the studied variables, probably because temperature was always within the optimum range for this species and the abundance of food supply in the study area independently of the season. The accumulated sediment on mussel clumps did not show any temporal variability with only significant differences among shores. The accumulated sediment was composed mainly by 
36

37

38

39

40

41

42

43

44

45

46

47

48

49

50

51

52

53

54

55

56

57

58

59

60

61

62

63

64

65

66

67

68

69

70

71

72

73

74

75

medium and coarse sand and it was correlated with mussel average size, condition index, but especially with the mussel clump thickness.

Subjects Ecology, Marine Biology

Keywords Ecosystem engineer, North east Atlantic, rocky shore, sediment stress.

\section{Introduction}

Mussels are important organisms in intertidal systems because they keep biodiversity, sheltering, supporting and enhancing diverse assemblages of invertebrates (Leigh et al., 1987; Seed \& Suchanek, 1992; Seed, 1996) inducing physical changes in the substrate and providing suitable space and resources for different species of animals and macroalgae (Thiel \& Ullrich, 2002; Loehle, 2004; Prado \& Castilla, 2006; Borthagaray \& Carranza, 2007). The Mediterranean mussel Mytilus galloprovincialis Lamark, 1819 is one of the most frequent and abundant native mussel species in the south Atlantic European and Mediterranean Sea rocky shores (Braby \& Somero, 2006). Recently, Lynch et al. (2020), have detected a northward range expansion of $M$. galloprocincialis along Irish shores, probably as a result of global warming. Additionally, $M$.

galloprovincialis is also a widespread invasive species in other regions like South Africa (De Moor \& Bruton, 1988). Moreover, M. galloprovincialis is an economically important species because of its high production (Guo et al., 2018). Because of that, it is vulnerable to recreational and commercial harvesting (Smith \& Murray, 2005). Aquaculture of marine bivalves accounts $14 \%$ of the global marine production (Wijsman et al., 2019). However, for mussels this practice, requires the exploitation of wild populations, involving the collection of young mussels' larvae directly from the water or harvesting of small mussels $(0.5-2 \mathrm{~cm})$ from intertidal and subtidal beds (Consellería de Pesca, Marisqueo y Acuicultura, 2000; Cáceres-Martínez \& Figueras, 2007; Figueras, 2007). This practice affects not only mussel juveniles but also adult stocks because it slows down the recovery of mussels (Harris et al., 2003), and thus it may influence the whole communities associated with mussels (Veiga et al., 2020).

Natural populations of $M$. galloprovincialis, are under the effects of natural and anthropogenic disturbances (Nicastro, McQuaid \& Zardi, 2019), which can have a strong influence on natural population dynamics (UNEP, 2006). Intertidal populations of M. galloprovincialis often live in mechanically stressful environments, being affected by natural ecological drivers like changes of temperature, salinity, concentration of suspended matter or phytoplankton (Braby \& Somero, 2006; Zardi et al., 2008; Garner \& Litvaitis, 2013; Araújo et al., 2020) and the presence of filamentous algae that promote the larval colonization (Ceccherelli \& Rossi, 1984). Among anthropogenic disturbances, coastal urbanisation is one of the most persistent and increasing threats due to an increase of ocean sprawl and high diversity of pollutants coming from industry and domestic products (Todd et al., 2019). Coastal urbanisation has proved to have negative effects on the abundance and size structure of intertidal M. galloprovincialis (Veiga et al., 2020). Other anthropogenic disturbances like harvesting or trampling have also proved to have negative effects on mussels populations (Smith \& Murray, 2005). Among the multiple stressors that can affect mussel populations, the sediment accumulated on rocky shores has been poorly studied. 
76

77

78

79

80

81

82

83

84

85

86

87

88

89

90

91

92

93

94

95

96

97

98

99

100

101

102

103

104

105

106

107

108

109

110

111

112

113

114

115

Airoldi (2003) suggests that sediment can interfere in the development of mussel beds, particularly the accumulation of sediment interferes with physical and biological processes that lead to a reduction of suitable habitats (Airoldi, 2003). The main negative effect described for sediment accumulation on mussel populations is the burial (e.g. Hutchison et al., 2016; Dos Santos et al., 2018) but that effect can be different among mussel species in function of their ability to emerge or resist burial (Zardi et al., 2008; Hutchison et al., 2016, 2020). Moreover, the sediment can be a reservoir of contaminants that can result toxic for marine animals (Long et al., 1996; Fichet, Radenac \& Miramand, 1998). Finally, sediment accumulation can also modify the services provided by mussels modifying the invertebrate assemblage diversity associated to mussel beds and facilitating the colonisation of mussel beds by soft bottoms macro- and meiobenthic species (e.g. Dos Santos et al., 2018).

Studies about patterns of variation in time and space of natural populations and assemblages are a chief goal in ecology, especially when they include economically relevant species with a key ecological role like M. galloprovincialis (Levin, 1992; Underwood \& Chapman, 2000). The understanding of variation in populations is essential to the management and conservation of species because, as natural and anthropogenic processes like sediment accumulation may be very variable in space and time, their effect on the population dynamics will also be very variable (Andrew \& Mapstone, 2006; Levin, 1992; Underwood, 1996; Benedetti-Cecchi, 2000; Bertocci et al., 2012). Bivalve molluscs show high plasticity on their responses and adaptation to local conditions (Bayne \& Widdows, 1978; Widdows et al., 1984; Tedengren et al., 1990; Navarro et al., 1991) so, their settlement and growth varies among regions, according to the local environment, but it can also vary along the year in response to oceanographic natural oscillations (Seed, 1976). In sedentary animals like mussels, their reproduction and growth are the only mechanisms to sustain populations (Seed, 1976). Consequently, exogenous and endogenous factors are crucial for controlling physiological rates and the reproduction (Orban et al., 2002; Nsgarajan, Lea \& Goss-Custard, 2006, Seed, 1976). Therefore, knowledge of the natural variability in time and space is decisive to understand population dynamics (Underwood, 1981) and for the management and conservation of the stocks of commercially exploited species, as well as the services provided by those species.

Nowadays, there is a lack of information about the spatial-temporal variability of $M$. galloprovincialis populations along the Atlantic coast of the Iberian Peninsula, where this species plays key ecological and economical roles. Similarly, the ability of M. galloprovincialis clumps to accumulate sediment on rocky shores is almost unexplored. The main aims of this study are to fill these gaps of knowledge and to explore the spatial-temporal patterns of $M$. galloprovincialis, and accumulated sediments on their clumps, along rocky shores in the North of Portugal. Different variables will be considered: density, spat stage, percentage cover, clump thickness, condition index and different size classes of mussels to achieve these objectives. Moreover, the spatial-temporal patterns of sediment accumulation in mussel clumps and its relationships with the mussel population attributes will be examined. 


\section{Materials \& Methods}

\section{Study area}

118 The study was done between January 2019 and December 2019 and included six rocky shores

119 along $90 \mathrm{~km}$ of the Northern Portuguese coast: Aguda (N 41 ${ }^{\circ} 04246$ ', W $\left.8^{\circ} 653254^{\prime}\right)$ it is an urban

120 schist platform shore with significant natural/anthropogenic sediment input and close to an

121 artificial seawall, Valadares ( 41 $^{\circ} 089167^{\prime}, \mathrm{W} 8^{\circ} 658374^{\prime}$ ) it is an urban schist platform shore

122 with significant natural/anthropogenic sediment input, Cabo do Mundo (N 41225741', W

$\left.1238^{\circ} 717976^{\prime}\right)$ it is an urban granitic shore with gentle slope in a very industrial area, Carreço (N

$1244^{\circ} 742040^{\prime}$, W $8^{\circ} 878418^{\prime}$ ) it is a non-urban schist shore with gentle slope and significant natural

125 sediment input, Forte do Cão (N 41 ${ }^{\circ} 798244^{\prime}$, W $\left.8^{\circ} 874848^{\prime}\right)$ it is a non-urban granitic shore with

126 gentle slope close to a storm-water outflow and Moledo (N 41 ${ }^{\circ} 822605^{\prime}$, W $8^{\circ} 874894^{\prime}$ ) it is a

127 non-urban granitic shore with gentle slope (Fig. 1). Along the Northern Portuguese coast,

128 intertidal area varies from soft to hard bottoms but they mostly present a mixture of both

129 substrates. Sampling was done during low tide in the mid tide level of the rocky shores, that

130 typically is dominated by the species M. galloprovincialis (Veiga et al., 2020). In the North of

131 Portugal, the spring - summer and the autumn - winter seasons are characterized by strong

132 differences in mean monthly precipitation, air and water temperature, hydrodynamic conditions,

133 wave height and storm frequency (Dias et al., 2002; Bertocci et al., 2012). The coastline is

134 largely straight and is exposed to wave action, which varies strongly with seasons (Dias et al.,

135 2002). In the spring - summer period the typical wave heights are between 1 and $3 \mathrm{~m}$, with

136 periods of 11-13 s (Dias et al., 2002) and swells direction generally is from $\mathrm{W}$ and NW. In the

137 autumn - winter period, the waves can reach around $7 \mathrm{~m}$ with periods of 13-18 s (Dias et al., 138 2002). The tidal regime of the study area is semidiurnal with the largest spring tides of $3.5-4.0$

$139 \mathrm{~m}$. Moreover, the studied area is subjected to a seasonal upwelling that provides nutrients and

140 increases the primary production in the water column during spring and summer months (Lemos

141 \& Pires, 2004). Along the sampling year 2019, in the autumn - winter period, mean value of air

142 temperature was $11.98^{\circ} \mathrm{C}$, with values ranging between $3.31^{\circ} \mathrm{C}$ and $22.42^{\circ} \mathrm{C}$. Mean

143 precipitation was $77.51 \mathrm{~mm}$, with values ranging between $34.5 \mathrm{~mm}$ and $145.75 \mathrm{~mm}$, being

144 December the month with more precipitation. In the spring - summer months, mean values of air

145 temperature were $19.16^{\circ} \mathrm{C}$, ranging between $4.13^{\circ} \mathrm{C}$ and $29.70^{\circ} \mathrm{C}$. During these months, the

146 mean precipitation was $31.03 \mathrm{~mm}$, with values ranging between $3.3 \mathrm{~mm}$ and $117.2 \mathrm{~mm}$

147 (http://www.ipma.pt/pt/index.html). Monthly values for seawater temperature, salinity and wave

148 height at the sampling area can be found in Figure 2. Values showed on Figure 2 were measured

149 every 60 minutes by an oceanographic buoy (model Seawach) placed at $42.12^{\circ} \mathrm{N}$ and $9.43^{\circ} \mathrm{W}$.

150 Values of temperature and wave height were measured during 2019 but, for salinity there are

151 many lacks of data for 2019 and thus, we included the data of 2018. All the data were obtained

152 from the public repository of Puertos del Estado webpage (http://www.puertos.es/es-

153 es/oceanografia/Paginas/portus.aspx ).

154 Sampling 
155 The sampling design included two seasons and three sampling dates within each season: spring -

156

157

158

159

160

161

162

163

164

165

166

167

168

169

170

171

172

173

174

175

176

177

178

179

180

181

182

183

184

185

186

187

188

189

190

191

192

193

194 summer (April, June and September) and autumn - winter (January, October and December). On each of these dates, the six studied shores were visited, and at each shore, two sites separated by $10 \mathrm{~s}$ of meters were randomly selected. At each site, the percentage of mussel's cover was calculated in four quadrats $(50 \times 50 \mathrm{~cm})$. Cover was estimated by dividing each quadrat into 25 sub-quadrates of $10 \times 10 \mathrm{~cm}$, attributing a scale from 0 , with an absence of mussels, to 4 , when all the quadrat $(10 \times 10 \mathrm{~cm})$ were covered by mussels, and accumulation up the 25 estimates (Dethier et al., 1993). In addition, four measures of mussel clump thickness were randomly taken within each of the four $50 \times 50 \mathrm{~cm}$ quadrats by introducing a rigid ruler until reaching the bottom of the clump. Within each one of the $50 \times 50 \mathrm{~cm}$ quadrats, one sample of $10 \times 10 \mathrm{~cm}$ was collected, by scraping all the mussels in this area, and stored in labelled bags. These samples were preserved in a mixture of formalin $4 \%$ with rose of Bengal neutralised with sodium tetraborate anhydrous (Borax). In the laboratory, samples were washed in a tower of sieves of $1000 \mu \mathrm{m}, 500 \mu \mathrm{m}, 250 \mu \mathrm{m}, 125 \mu \mathrm{m}$ and $63 \mu \mathrm{m}$ mesh size. For each sample, twenty random mussels from the $1000 \mu \mathrm{m}$ sieve were separated to be measured with a calliper. Measured mussels were grouped in the following size classes: Class 1: $<10 \mathrm{~mm}$, Class 2: 10-20 mm, Class 3: 20-30 mm, Class 4: 30-40 mm, Class 5: 40-50 mm and Class 6: $>50 \mathrm{~mm}$. Additionally, 10 mussels per replicate were opened with a surgical blade and the shell was separated from the soft body. Afterwards, they were dried and weighed to calculate the condition index as the ratio between soft tissues dry weight and the shell dry weight. Residues retained in the sieves of 500 $\mu \mathrm{m}$ and $1000 \mu \mathrm{m}$ were sorted in a dissection microscope and all the mussels were collected and counted. To evaluate mussels in the spat stage (i.e. mussels with size between 500 and $1000 \mu \mathrm{m}$ ), as a proxy of recruitment, the number of mussels retained in the $500 \mu \mathrm{m}$ mesh size was counted. The amount of sediment retained at each mesh size $(1000 \mu \mathrm{m}, 500 \mu \mathrm{m}, 250 \mu \mathrm{m}, 125 \mu \mathrm{m}$ and 63 $\mu \mathrm{m})$ was evaluated by drying the sieve content at $65^{\circ} \mathrm{C}$ for about $12 \mathrm{~h}$ and weighting.

\section{Data analyses}

Differences in the total density, spat density, percentage cover, mussel size classes and the amount of sediment retained on mussel clumps (total and different sediment sizes) were examined with analyses of variance (ANOVA). These analyses were based on a four way model including Season (Se) with two 2 levels: autumn - winter and spring - summer, as a fixed orthogonal factor, Date (Da) with 3 levels, as a random factor nested in Se, Shore (Sh) with 6 levels: Aguda, Valadares, Cabo do Mundo, Moledo, Carreço and Forte do Cão, as a fixed orthogonal factor and Site (Si) with 2 levels, as a random factor nested in all the previous factors, considering 4 replicates per site. ANOVA was also used to test for differences on thickness and condition index, but these analyses were based on a five-way model, including all the factors above mentioned and Plot (Pl), as an additional random factor, nested in $\mathrm{Se} x \mathrm{Da} x \mathrm{Sh} x \mathrm{Si}$, with 4 and 10 replicates for thickness and condition index, respectively. Cochran's $\mathrm{C}$ test was done to test for homogeneity of variances. In some cases, when Cochran's $C$ test was significant $(p<0.05)$ data were $\operatorname{Ln}(X+1)$ transformed with the objective of removing heterogeneity of variances. When transformation was not possible, untransformed data were analysed and results 
195

196

197

198

199

200

201

202

203

204

205

206

207

208

209

210

211

212

213

214

215

216

217

218

219

220

221

222

223

224

225

226

227

228

229

230

231

232 233

were considered only if significant at $\mathrm{p}<0.01$, to compensate for the increased probability of type I error (Underwood, 1997). Whenever ANOVA demonstrated significant differences $(\mathrm{p}<0.05)$ a post hoc Student-Newman-Keuls (SNK) test was done to explore differences. Finally, in order to explore the relationship between total sediment content and mussel descriptors, rank correlation analyses were done for each descriptor. Due to the non-normal distribution of the data, Spearman's rank correlation was used.

\section{Results}

\section{Spatial and temporal patterns of mussel descriptors}

ANOVA results for the percentage cover detected significant differences among Shores (Table 1). Post hoc analysis was not able to provide an alternative hypothesis, probably due to its lower power (Underwood, 1997), (Fig. 3). For total and spat density, the interaction between shore and date (Sh x Da) was significant (Table 1). Post hoc analysis for total density showed a homogeneous pattern for the first three dates (Jan, Apr, Jun) but, significant differences were detected in the last three months (Sep, Oct, Dec) (Fig. 4). Results for spat stage showed a similar pattern as total density, but only Aguda showed significant differences in the last two months (Oct, Dec) (Fig. 5).

Condition index and clump thickness showed significant differences for the interaction between shore and date (Sh x Da) (Table 2). Post hoc analysis showed significant differences in the first four months (Jan, Apr, Jun, Sep). On the other hand, in October, Valadares showed significantly higher values than the remaining shores (Fig. 6). For bed thickness, post hoc analysis showed significant differences in the first two months (Jan, Apr) for several shores (Fig. 7).

The size classes 1 and 3 did not show significant differences among seasons or shores (Table 3 ). However, ANOVA detected significant differences for the interaction between shore and date (Sh x Da) in Classes 2, 4, 5 and 6 (Table 3). The post hoc analyses showed significant differences between shores in June and December for Class 2 (Fig. S1). For Class 4, significant differences were detected in June and October (Fig. S2). For the Class 5, post hoc analysis pointed out differences in January, April, September and December, (Fig. S3). For Class 6, post hoc analysis showed significant differences in January, October. (Fig. S4).

The sediment content in clumps differed significantly among shores both for total sediment and different sediment sizes (Table 4) (Fig. 8).

\section{Relationship between sediment content in clumps and different mussel attributes}

Spearman's rank correlations showed that total sediment content significantly increased with mussel clumps thickness $(\mathrm{R}=0.551, \mathrm{p}<0.01)$. Moreover, a significant positive correlation was found between total sediment content and condition index $(\mathrm{R}=0.136, \mathrm{p}<0.05)$ and with the average mussel size $(\mathrm{R}=0.18, \mathrm{p}<0.05)$ but the correlation coefficients were much lower than that obtained for thickness. However, correlation between total sediment and cover $(\mathrm{R}=0.0356$, $\mathrm{p}>0.05)$, density $(\mathrm{R}=-0.05, \mathrm{p}>0.05)$ or spat stage $(\mathrm{R}=-0.0345, \mathrm{p}>0.05)$ were not significant. 


\section{Discussion}

235 This study documented the lack of seasonality for all the studied descriptors in $M$.

236

237

238

239

240

241

242

243

244

245

246

247

248

249

250

251

252

253

254

255

256

257

258

259

260

261

262

263

264

265

266

267

268

269

270

271

272

273 galloprovincialis along the North coast of Portugal. However, significant differences were shown on the term Sh x Da for density, spat stage, clump thickness, condition index and size classes, demonstrating that drivers shaping these descriptors have limited effects at spatial (i.e. shores) and temporal (i.e. date) scales. Moreover, percentage cover and sediment content on mussel clumps showed significant differences just among shores indicating that the different drivers that could influence these descriptors, have a constant effect along the explored time scales (Season and Date), changing only at spatial scale.

The comparison of our results with previous studies is difficult due to the lack of information about spatial-temporal variability of $M$. galloprovincialis populations in the Iberian Peninsula. However, studies done in other regions (e.g. South-west England and Italian coast) demonstrated differences between seasons for the condition index of M. galloprovincialis (Orban et al., 2002; Ivankovic et al., 2005). Moreover, studies on benthic assemblage seasonality done in North of Portugal were focused on tide pools (Rubal et al., 2011; Bertocci et al., 2012) and pointed out that benthic assemblages (dominated by macroalgae) showed significant differences between seasons. Results of these studies contrast with our findings for M. galloprovincialis suggesting that drivers that shape mussel populations probably are different to those influencing tide pool macroalgae assemblages. In contrast with our results, other invertebrates considered as ecosystem engineers, such as Sabellaria worms (Gravina et al., 2018), showed seasonality with a growing phase beginning in summer until fall, a degeneration phase in winter and spawning in spring (Peharda et al., 2007; Gravina et al., 2018).

Mytilus galloprovincialis showed a homogenous pattern along time for percentage cover. The absence of seasonality or other temporal variability in this descriptor suggests that mussels occupy similar areas of rocky shores along the year, independently of the season and date. The study by Boaventura and Re (2002), done along the Portuguese coast, showed that the abundance of M. galloprovincialis declined from North to South of Portugal; this is in agreement with the high values of the percentage cover found in our study. The percentage cover is determined by the abundance and size of individuals, which is affected by growth, mortality and recruitment (Roughgarden, Iwasa \& Baxter, 1985; Petraitis, 1995). Therefore, results for the percentage cover are in concordance with our results for density and spat stage that did not show any seasonality. The constant amount of spat stage along the year suggests a constant recruitment and spawning for M. galloprovincialis in the studied area. There are many studies about the reproductive cycle of $M$. galloprovincialis showing contrasting conclusions (e.g. Seed, 1976; Nsgarajan and Lea, 2006). Seed (1976) suggests that spawning in Mytilus is regulated by a combination of external and internal factors but, the variation of seawater temperature is the most crucial one and that low temperatures reached in winter and autumn can inhibit mussel spawning. Seed (1976) pointed out that optimum seawater temperature for the genus Mytilus ranges between $10^{\circ} \mathrm{C}$ and $20^{\circ} \mathrm{C}$, which can influence not just the spawning but also the growth. For the specie M. galloprovincialis the optimal temperature for the population growth rate ranges

PeerJ reviewing PDF | (2020:08:52360:4:0:NEW 26 Apr 2021) 
274 between $13^{\circ} \mathrm{C}$ and $18^{\circ} \mathrm{C}$ (Yoann \& Cédric, 2018). As temperature is different between regions 275 and may change considerably from year to year (Seed, 1976), the reproductive cycle of $M$. 276 galloprovincialis can present different seasonal patterns according to the studied region and even 277 among years. On the other hand, the study by Ceccherelli and Rossi (1984) does not exclude the 278 probability of spat stage occurs independently at different times along the whole year, with 279 different values among months. Therefore, M. galloprovincialis can present different 280 reproductive phenology at different regions (Ceccgerelli \& Rossi, 1984). Constant recruitment 281 and reproduction along the year in our studied area is possible since seawater temperature is 282 around the optimum range described by Yoann \& Cédric, 2018 during all year. The few 283 significant differences detected for total and spat abundance could be the result of local natural 284 or anthropogenic disturbances.

285 The condition index of mussels is affected through a variety of intrinsic and extrinsic factors, like 286 food availability, sea temperature, salinity and gametogenic cycle (Okumus \& Stirling, 1998). 287 Many studies (e.g. Çelik et al., 2012) state that the condition index shows a seasonal variability; 288 achieving a maximum during gonadal development and decreases when spawning period starts. 289 However, other studies (e.g. Orban et al., 2002) showed that the condition index registered a 290 similar value along the year, in concordance with our results. The lack seasonal variability 291 suggest that mussels from north of Portugal do not have a defined period for gonadal 292 development and spawning. Therefore, mussels seem to be able to spawn along the whole year, 293 explaining in this way the constant recruitment that suggests the spat density results. As percentage cover, clump thickness provides information about the habitat furnished by $M$. galloprovincialis for the other species. The percentage cover gives information about the habitat provided by M. galloprovincialis along the shore (horizontal) while thickness depends on the accumulation of different layers of mussels, providing three-dimensional habitat (vertical). The clump thickness of mussel populations in the intertidal is strongly influenced by wave action (Zardi, McQuaid \& Nicastro, 2007). Therefore, the magnitude of the hydrodynamic forces along the year can affect the thickness of mussel clumps due to dislodgment of thick clumps during storms (Zardi et al., 2006). Results showed that mussel clumps thickness differs among shores and dates but not between seasons. Therefore, seasonal changes on wave height seems to play a minor role in shaping the clump thickness since the wave height, in the studied area, has a clear seasonal pattern (i.e. higher during Winter-Autumn) in contrast with our findings for clump thickness. Therefore, observed differences among dates and shores may be the result of local shoreline characteristics.

The size classes also showed absence lack of seasonality. The growth of mussels can be assessed by the size, which usually is related to age, but it is also dependent on environmental conditions (Seed, 1976). Peharda et al. (2007) showed that the growth of M. galloprovincialis is slow at temperatures above $21^{\circ} \mathrm{C}$ and at temperatures below $10^{\circ} \mathrm{C}$, but also found that food availability can be an important driver for the growth of mussels. The lack of seasonal pattern on the abundance of different size classes can be the result of a continuous recruitment and growth due to optimal environmental conditions on the studied area. In general the lack of seasonal changes 
314 on the M. galloprovincialis population on the studied area contrast with the seasonal changes on 315 water and air temperature, wave action or upwelling events related with the considered seasons.

316 However, the recorded changes on temperature in the North of Portugal are around the optimum 317 range of M. galloprovincialis. Moreover, Abrantes (1999) showed significant differences in the 318 phytoplankton biomass, the main food source for M. galloprovincialis, between August and 319 January along the coast of Portugal. Despite a reduction on the phytoplankton biomass during

320

321

322

323

324

325

326

327

328

329

330

331

332

333

334

335

336

337

338

339

340

341

342

343

344

345

346

347

348

349

350

351

352

353 winter, this reduction is not so marked as in the centre or south of Portugal (Abrantes, 1999). Therefore, the availability of food during the winter in the north of Portugal may explain the high percentage cover in the north observed by Boaventura et al. (2002) and the lack of seasonal variability observed in our study.

However, significant differences were detected among shores or among shores and dates. These differences could be caused by non-seasonal physical and biological processes such as trampling, harvesting, pollution events, predation, or parasitism that could vary between dates and shores independently of the season. For example, the effects of harvesting and trampling could also vary among shores, for instance, in function of their accessibility to humans (Smith \& Murray, 2005; Rius, Kaehler \& McQuaid, 2006; McPhee, 2017). However, differences in the morphology or the orientation to wave exposure of the studied shores could be among plausible drivers for the descriptors of percentage cover and sediment content that only showed significant differences between shores.

Results of our study also showed a lack of variability on sediment accumulation along the two studied temporal scales (i.e. season and date), although significant differences were found between shores. Similar results were found in Argentina (Dos Santos et al., 2018) where no seasonal pattern in the sediment accumulated on mussel beds was found. However, the amount of sediment that reaches the shores can vary seasonally, as found by previous studies on South Africa (Zardi et al., 2006) and Argentina (Dos Santos et al., 2018). Therefore, despite the variable supply of sediments, results of our study and that by Dos Santos et al. (2018) suggest a limited and constant capacity of mussel beds to retain sediment under natural conditions.

However, the ability to accumulate sediment showed significant differences among rocky shores in our study. These results contrast with those found by Dos Santos et al. (2018) where no significant differences were found on the sediment accumulated on mussel beds between their studied sites. In our study we have considered a broader spatial scale than that in the study by Dos Santos et al. (2018). Therefore, at each shore, local currents, bottom topography, tidal speed and different sources of sediment may have resulted in the heterogeneous spatial pattern found. Moreover, our results showed a positive relationship between sediment accumulation and mean mussel size, condition index and clump thickness, however, the correlation coefficients of average mussel size and condition index were very low and only clump thickness, with a correlation coefficient above 0.5 , may play a relevant role in shaping sediment accumulation. Results also showed that $500 \mu \mathrm{m}$ and $1000 \mu \mathrm{m}$ sediment size categories were the most abundant ones. This observation, is in agreement with the sediment size found in some northern Portuguese sandy beaches (Veiga et al. 2014) suggesting that sandy beaches and rocky shores 
354

355

356

357

358

359

360

361

362

363

364

365

366

367

368

369

370

371

372

373

374

375

376

377

378

379

380

381

382

383

384

385

386

387

388

389

receive sediment from the same or similar sources. It is also noticeable the low amount of $63 \mu \mathrm{m}$ sediment accumulated because burial by fine sediments induces higher mortality than burial by coarse sediments (Hutchison et al., 2016). Moreover, Zardi et al. (2006) showed that $M$. galloprovincialis has higher tolerance to burial than Perna perna, probably because its larger palpial labs are more efficient sorting particles and avoiding gill damage.

\section{Conclusions}

The lack of seasonality and reduced temporal variability found for M. galloprovincialis in the study area may be due to the optimal water temperature and food availability along the whole year. The lack of temporal variability on the amount of sediment accumulated on mussel clumps suggest constant input of sediment that only differs among shores and may be influenced by clump thickness.

\section{Acknowledgements}

We are grateful to the editor Mark Costello, Sandra Fiori and an anonymous referee for helpful comments and suggestions, which greatly improved this paper. We are also very grateful to Dr.

Laura Guerrero for her help with figures.

\section{References}

Abrantes F, Moita MT. 1999. Water column and recent sediment data on diatoms and coccolithophorids off Portugal confirm sediment record of upwelling events. Oceanologica 22(3):319-336 DOI: 10.1016/S0399-1784(99)80034-6

Airoldi L. 2003. The effects of sedimentation on rocky coast assemblages. Oceanography and Marine Biology 41:161-236 DOI: 10.1201/9780203180570-23

Andrew NL, Mapstone BD. 2006. Sampling and the description of spatial pattern in marine ecology. Oceanography and Marine Biology 52: 39-90 DOI: 10.1016/01980254(88)92605-2

Araújo J, Soares F, Medeiros A, Bandarra NM, Freire M, Falcão M, Pousão-Ferreira P. 2020. Depth effect on growth and fatty acid profile of Mediterranean mussel (Mytilus galloprovincialis) produced on a longline off south Portugal. Aquaculture International 28: 927-946 DOI:10.1007/s10499-019-00504-0

Bayne BL, Widdows J. 1978. The physiological ecology of two populations of Mytilus edulis L. Oecologia 37,137-162 DOI: 10.1007/BF00344987

Benedetti-Cecchi L. 2000. Priority effects, taxonomic resolution, and the prediction of variable patterns of colonisation of algae in littoral rock pools. Oecologia 123:265-274 DOI: $10.1007 / \mathrm{s} 004420051013$ 
390

391

392

393

394

395

396

397

398

399

400

401

402

403

404

405

406

407

408

409

410

411

412

413

414

415

416

417

418

419

420

421

422

423

424

425

426

427

428

429

Bertocci I, Araújo R, Incera M, Arenas F, Pereira R, Abreu H, Larsen K, Sousa-Pinto I. 2012. Benthic assemblages of rock pools in northern Portugal : seasonal and between-pool variability. Scientia Marina 76(4):781-789 DOI: 10.3989/scimar.03669.21

Boaventura D, Ré P, Fonseca LC, Hawkins SJ. 2002. Intertidal rocky shore communities of the continental Portuguese coast : Analysis of distribution patterns. Marine Ecology 23(1):6990 DOI: 10.1046/j.1439-0485.2002.02758.x

Borthagaray AI, Carranza A. 2007. Mussels as ecosystem engineers: their contribution to species richness in a rocky littoral community. Acta Oecologica 31:243-250 DOI: 10.1016/j.actao.2006.10.008

Braby CE, Somero GN. 2006. Ecological gradients and relative abundance of native (Mytilus trossulus) and invasive (Mytilus galloprovincialis) blue mussels in the California hybrid zone. Marine Biology148: 1249-1262 DOI: 10.1007/s00227-005-0177-0

Cáceres-Martínez J, Figueras A. 2007. Fijación de los juveniles del mejillón: fijación del mejillón. In: Figueras A, ed. Biología y Cultivo del Mejillón (Mytilus galloprovincialis) en Galicia. CSIC - CSIC Press (Spain) 72-93.

Ceccgerelli VU, Rossi R. 1984. Settlement, growth and production of the mussel Mytilus galloprovincialis. Marine Ecologic Progress Series 16:173-184 DOI: 10.3354/meps016173

Çelik MY, Karayücel S, Karayücel I, Öztürk R, Eyüboglu B. 2012. Meat yield, condition index and biochemical composition of mussels (Mytilus galloprovincialis Lamarck, 1819) in Sinop, South of the Black Sea. Journal of Aquatic Food Product Technology 21:198-205 DOI: $10.1080 / 10498850.2011 .589099$

Consellería de Pesca, Marisqueo y Acuicultura. 2000. ORDEN de 26 de Octubre de 2000 por la que se regula la extracción de semilla de mejillón en bancos naturales., pp. 15681-15684. Diario Oficial de Galicia 228: 15681-15684 https://www.xunta.gal/dog/Publicados/2000/20001124/Anuncio15CB6_es.html (acessed 5 July 2020)

De Moor, IJ, Bruton, MN (Compilers). 1988. Atlas of alien and translocated indigenous aquatic animals in southern Africa. National Scientific Programmes Unit: CSIR, SANSP Report 144, 1988, pp 317. Available at http://hdl.handle.net/10204/2416 (accessed 27 August 2020)

Dethier MN, Graham ES, Cohen S, Tear LM. 1993. Visual versus random-point percent cover estimations: "objective" is not always better. Marine Ecology Progress Series 96:93-100 DOI: $10.3354 /$ meps096093

Dias JMA, Gonzalez R, Garcia C, Diaz-del-Rio V. 2002. Sediment distribution patterns on the Galicia-Minho continental shelf. Oceanography 52:215-231 DOI: 10.1016/S00796611(02)00007-1

Dos Santos EP, Carcedo MC, Zotelo C, Fiori SM. 2018. Effects of erosion-accretion processes on a community dominated by Brachidontes rodriguezzi (Mollusca: Mytilidae) on a rocky outcrop of the South Atlantic coast. Journal of Marine Systems 187:146-155 DOI: 10.1016/j.jmarsys.2018.07.006 
430 Fichet D, Radenac G, Miramand P. 1998. Experimental estudies of impacts of harbour sediments

431

432

433

434

435

436

437

438

439

440

441

442

443

444

445

446

447

448

449

450

451

452

453

454

455

456

457

458

459

460

461

462

463

464

465

466

467

468

469 resuspension to marine invertebrates larvae: bioavailability of $\mathrm{Cd}, \mathrm{Cu}, \mathrm{Pb}$ and $\mathrm{Zn}$ and toxicity. Marine Pollution Bulletin 36(7-12): 509-518 DOI: 10.1016/S0025326X(97)00190-2

Figueras AJ. 2007. Biología y Cultivo del Mejillón (Mytilus galloprovincialis) en Galicia. CSIC CSIC Press

Garner YL, Litvaitis MK. 2013. Effects of wave exposure, temperature and epibiont fouling on byssal thread production and growth in the blue mussel, Mytilus edulis, in the Gulf of Maine. Journal of Experimental Marine Biology and Ecology 446:52-56 DOI: 10.1016/j.jembe.2013.05.001

Gravina MF, Cardone F, Bonifazi A, Bertrandino MS, Chumienti G, Longo C, Marzano CN, Moretti M, Lisco S, Moretti V, Corriero G, Giangrande A. 2018. Sabellaria spinulosa ( Polychaeta, Annelida ) reefs in the Mediterranean Sea : Habitat mapping, dynamics and associated fauna for conservation management. Estuarine, Coastal and Shelf Science 200:248-257 DOI: 10.1016/j.ecss.2017.11.017

Guo C, Chen Y, Li W, Xie S, Lek S, Li Z. 2018. Food web structure and ecosystem properties of the largest impounded lake along the eastern route of China's South-to-North Water Diversion Project. Ecological Informatics 43:174-184 DOI: 10.1016/j.ecoinf.2017.12.003

Harris J, Branch G, Sibiya C, Bill C. 2003. The Sokhulu subsistence mussel-harvesting project: co-management in action. Chapter 4. In: Hauck M, Sowman M, eds. Waves of Change: coastal and fisheries co-management in Southern Africa. Cape Town: UCT Press, 61-98. Hutchison ZL, Green DH, Burrows MT, Jackson AC, Wilson B, Last KS. 2020. Survival strategies and molecular responses of two marine mussels to gradual burial by sediment. Journal of Experimental Marine Biology and Ecology 527:151364 DOI: 10.1016/j.jembe.2020.151364

Hutchison ZL, Hendrick VJ, Burriwa MT, Wilson B, Last KS. 2016. Buried Alive: The behavioural response of the mussels, Modiolus modiolus and Mytilus edulis to dudden burial by sediment. PloS One 11(3): e0151471 DOI: 10.1371/journal.pone.0151471

Instituto Português do Mar e da Atmosfera. Boletins Climatológicos. Available at http://www.ipma.pt/pt/index.html (accessed 5 June 2020)

Ivankovic D, Pavicic J, Erk M, Filipovic-Marijic V, Raspor B. 2005. Evaluation of the Mytilus galloprovincialis Lam. . digestive gland metallothionein as a biomarker in a long-term field study : Seasonal and spatial variability. Marine Pollution Bulletin 50:1303-1313 DOI: 10.1016/j.marpolbul.2005.04.039.

Leigh ECJr, Paine RT, Quinn JF, Suchanek TH. 1987. Wave energy and intertidal productivity. Proceedings of the National Academy of Sciences of the United States of America 84:13141318 DOI: $10.1073 /$ pnas.84.5.1314

Lemos RT, Pires H. 2004. The upwelling regime off the west Portuguese coast, 1941-2000. International Journal of Climatology 24:511-524 DOI: 10.1002/joc.1009

Levin SA. 1992. The problem of pattern and scale in ecology. Ecological society of America

Peer) reviewing PDF | (2020:08:52360:4:0:NEW 26 Apr 2021) 
470

471

472

473

474

475

476

477

478

479

480

481

482

483

484

485

486

487

488

489

490

491

492

493

494

495

496

497

498

499

500

501

502

503

504

505

506

507

508

509

73:1943-1967 DOI: $10.2307 / 1941447$

Loehle C. 2004. Challenges of ecological complexity. Ecological Complexity 1:3-6 DOI: 10.1016/j.ecocom.2003.09.001

Long ER, Robertson A, Wolfe DA, Hameedi J, Sloane GM. 1996. Estimates of the spatial extent of sediment toxicity in major US estuaries. Environmental Science \& Technology 30:35853592 DOI: $10.1021 / \mathrm{es} 9602758$

Lynch SA, Coghlan A, Leary BO, Morgan E, Culloty SC. 2020. Northward establishment of the mediterranean mussel Mytilus galloprovincialis limited by changing climate. Biology Invasions 22:2725-2736 DOI: 10.1007/s10530-020-02294-6

McPhee DP. 2017. Urban recreational fisheries in the australian coastal zone: The sustainability challenge. Sustainability 9:1-12 DOI: 10.3390/su9030422

Navarro E, Iglesias JIP, Camacho AP, Labarta U, Beiras R. 1991. The physiological energetics of mussels (Mytilus galloprovincialis Lmk.) from diferent cultivation rafts in the Ria de Arosa (Galicia,N.W. Spain). Aquaculture, 94:197-212 DOI: 10.1016/0044-8486(91)90118Q

Nicastro KR, McQuaid CD, Zardi GI. 2019. Between a rock and a hard place : combined effect of trampling and phototrophic shell-degrading endoliths in marine intertidal mussels. Marine Biodiversity 49:1581-1586 DOI: 10.1007/s12526-018-0924-3

Nsgarajan R, Lea SWG, Goss-Custard J. 2006. Seasonal variations in mussel, Mytilus edulis L . shell thickness and strength and their ecological implications. Journal of Experimental Marine Biology and Ecology 339:241-250 DOI: 10.1016/j.jembe.2006.08.001

Okumus I, Stirling HP. 1998. Seasonal variations in the meat weight, condition index and biochemical composition of mussels (Mytilus edulis L.) in suspended culture in two Scottish sea lochs. Aquaculture 159(3-4):249-261 DOI: 10.1016/S0044-8486(97)00206-8

Orban E, Lena G Di, Nevigato T, Casini I, Marzetti A, Caproni R. 2002. Seasonal changes in meat content, condition index and chemical composition of mussels (Mytilus galloprovincialis) cultured in two different Italian sites. Food Chemistry 77:57-65 DOI: 10.1016/S0308-8146(01)00322-3

Peharda M, Zupan I, Baveevié L, Frankié A, Klanjsflcek T. 2007. Growth and condition index of mussel Mytilus galloprovincialis in experimental integrated aquaculture. Aquaculture Research 38:1714-1720 DOI: 10.1111/j.1365-2109.2007.01840.x

Petraitis PS. 1995. The role of growth in maintaining spatial dominance by mussels (Mytilus edulis). Ecology 76:1337-1346 DOI: 10.2307/1940940

Prado L, Castilla JC. 2006. The bioengineer Perumytilus purpuratus (Mollusca: Bivalvia) in central Chile: biodiversity, habitat structural complexity and environmental heterogeneity. Jounal of the Marine Biological Association of the UK 86:417-421 DOI: $10.1017 / \mathrm{S} 0025315406013282$

Rius M, Kaehler S, McQuaid CD. 2006. The relationship between human exploitation pressure and condition of mussel populations along the south coast of South Africa. South African Journal of Science 102:130-136 
510 Roughgarden J, Iwasa Y, Baxter C. 1985. Demographic-theory for an openmarine population

511

512

513

514

515

516

517

518

519

520

521

522

523

524

525

526

527

528

529

530

531

532

533

534

535

536

537

538

539

540

541

542

543

544

545

546

547

548

549 with space-limited recruitment. Ecology 66:54-67 DOI: 10.2307/1941306

Rubal M, Veiga P, Vieira R, Sousa-Pinto I. 2011. Seasonal patterns of tidepool macroalgal assemblages in the North of Portugal . Consistence between species and functional group approaches. Jornal of Sea Research 66:187-194 DOI: 10.1016/j.seares.2011.07.003

Seed R. 1976. Ecology. In: Bayne BL ed. Marine mussels: their ecology and physiology. Cambridge: Cambridge University Press, , 13-67.

Seed R. 1996. Patterns of biodiversity in the macro-invertebrate fauna associated with mussel patches on rocky shores. Jounal of the Marine Biological Association of the UK 76:203210 DOI: $10.1017 /$ S0025315400029131

Seed R, Suchanek TH. 1992. Population and community ecology of Mytilus. In: Gosling E, ed. The mussel Mytilus: ecology, physiology, genetics and culture. London: Elsevier, , 87-169.

Smith JR, Murray SN. 2005. The effects of experimental bait collection and trampling on a Mytilus californianus mussel bed in southern California. Marine Biology 147:699-706 DOI: 10.1007/s00227-005-1619-4

Tedengren M, Andrë C, Johannesson K, Kautsky N. 1990. Genotypic and phenotypic diferences between Baltic and North Sea populations of Mytilus edulis evaluated through reciprocal transplantations. III. Physiology. Marine Ecology Progress Series 59:221-227 DOI: 10.3354/meps059203

Thiel M, Ullrich N. 2002. Hard rock versus soft bottom: the fauna associated with intertidal mussel beds on hard bottoms along the coast of Chile, and considerations on the functional role of mussel beds. Helgoland Marine Research 56:21-30 DOI: 10.1007/s10152-0010098-3

Todd PA, Heery EC, Loke LHL, Thurstan RH, Kotze DJ, Swan C. 2019. Towards an urban marine ecology: characterizing the drivers, patterns and processes of marine ecosystems in coastal cities. OIKOS 128:1215-1242 DOI: 10.1111/oik.05946

Underwood AJ. 1981. Structure of a rocky intertidal community in New South Wales: patterns of vertical distribution and seasonal changes. Journal of Experimental Marine Biology and Ecology 51:57-85 DOI: 10.1016/0022-0981(81)90154-4

Underwood AJ. 1997. Experiments in ecology: their logical design and interpretation using analysis of variances. Cambridge: Univeristy Press

Underwood AJ, Chapman MG. 1996. Scales of spatial patterns of distribution of intertidal invertebrates. Oecologia 107:212-224 DOI: 10.1007/BF00327905

Underwood AJ, Chapman MG, Connell SD. 2000. Observations in ecology: you can't make progress on processes without understanding the patterns. Journal of Experimental Marine Biology and Ecology 250:97-115 DOI: 10.1016/S0022-0981(00)00181-7

UNEP 2006. Marine and coastal ecosystems and human wellbeing: A synthesis report based on the findings of the Millennium Ecosystem Assessment. UNEP. Available at https://www.unenvironment.org/resources/report/marine-and-coastal-ecosystems-andhuman-well-being-synthesis-report-based-findings (accessed 9 August 2020) 
550 Veiga P, Ramos-Oliveira C, Sampaio L, Rubal M. 2020. The role of urbanisation in affecting

551

552

553

554

555

556

557

558

559

560

561

562

563

564

565

566

567

568

569

570

571

572

573

574

575

576 Mytilus galloprovincialis. PLoS ONE 15(5): e0232797. DOI: 10.1371/journal.pone.0232797

Widdows J, Donkin P, Salked PN, Cleary JJ, Lowe DM, Evans SV, Thompson PE. 1984. Relative importance of environmental factors in determining physiological diferences between two populations of mussels (Mytilus edulis). Marine Ecology Progress Series 17:33-47 DOI: 10.3354/meps017033

Wijsman JWM, Troost K, Fang J, Roncarati A. 2019. Global production of marine bivalves. Trends and challenges. In: Smaal A, Ferreira J, Grant J, Petersen J, Strand Ø eds. Goods and services of marine bivalves. Switzerland: Springer, Cham, 7-26. DOI: 10.1007/978-3319-96776-9_2

World sea temperatures. Portugal. Available at https://www.seatemperature.org/ (accessed 27 June 2020)

Yoann T, Cédric B. 2018. Assessing the sensivity of bivalve populations to global warming using an individual-based modelling approach. Global Change Biology 24:4581-4597 DOI: $10.1111 / \mathrm{gcb} .14402$

Zardi GI, McQuaid CD, Nicastro KR. 2007. Balancing survival and reproduction : seasonality of wave action, attachment strength and reproductive output in indigenous Perna perna and invasive Mytilus galloprovincialis mussels. Marine Ecology Progress Series 334:155-163 DOI: $10.3354 / \mathrm{MEPS} 334155$

Zardi GI, Nicastro KR, McQuaid CD, Erlandsson J. 2008. Sand and wave induced mortality in invasive (Mytilus galloprovincialis) and indigenous (Perna perna) mussels. Marine Biology 153: 853-858 DOI: 10.1007/s00227-007-0857-z

Zardi GI, Nicastro KR, McQuaid CD, Rius M, Porri F. 2006. Hydrodynamic stress and habitat partitioning between indigenous (Perna perna) and invasive (Mytilus galloprovincialis) mussels : constraints of an evolutionary strategy. Marine Biology 150:79-88 DOI: $10.1007 / \mathrm{S} 00227-006-0328-\mathrm{Y}$ 


\section{Table $\mathbf{1}$ (on next page)}

Significant differences for percentage cover, density and spat of $M$. galloprovincialis at the different studied temporal and spatial scales.

Table 1. Summary of univariate analyses of variance (ANOVA) for percentage cover, density and spat density of M. galloprovincialis. Significant differences indicated in bold. n.s.: not significant, ${ }^{*} p<0.05^{* *} p<0.01 * * * 0.001$ 
1 Table 1. Summary of univariate analyses of variance (ANOVA) for percentage cover, density and spat density of M. galloprovincialis.

2 Significant differences indicated in bold. n.s.: not significant, ${ }^{*} \mathrm{p}<0.05^{* *} \mathrm{p}<0.01{ }^{* * *} \mathrm{p}<0.001$

\begin{tabular}{|c|c|c|c|c|c|c|c|c|}
\hline \multirow{2}{*}{ Source of variation } & \multirow{2}{*}{ df } & \multicolumn{2}{|c|}{ \%Cover } & \multicolumn{2}{|c|}{ Density } & \multicolumn{2}{|c|}{ Spat density } & \multirow{2}{*}{ F versus } \\
\hline & & MS & $\mathbf{F}$ & MS & $\mathbf{F}$ & MS & $\mathbf{F}$ & \\
\hline Season $=$ Se & 1 & 1262.53 & 0.66 & 0.14 & 0.01 & 0.62 & 0.02 & $\mathrm{Da}(\mathrm{Se})$ \\
\hline Date $(\mathrm{Se})=\mathrm{Da}(\mathrm{Se})$ & 4 & 1902.84 & $7.14^{* * *}$ & 10.07 & $13.56^{* * *}$ & 26.04 & $20.39^{* * *}$ & $\mathrm{Si}(\operatorname{SexDaxSh})$ \\
\hline Shore $=$ Sh & 5 & 1340.44 & $2.86^{*}$ & 4.05 & 2.34 & 5.57 & 2.13 & $\mathrm{ShxDa}(\mathrm{Se})$ \\
\hline $\operatorname{Site}(\operatorname{Sh})=\operatorname{Si}(\operatorname{SexDaxSh})$ & 36 & 266.62 & $2.55^{* * *}$ & 0.74 & $3.31^{* * *}$ & 1.28 & $3.14^{* * *}$ & Residual \\
\hline SexSh & 5 & 260.39 & 0.56 & 1.92 & 1.11 & 4.70 & 1.79 & $\mathrm{ShxDa}(\mathrm{Se})$ \\
\hline ShxDa(Se) & 20 & 468.49 & 1.76 & 1.73 & $2.33^{*}$ & 2.62 & $2.05^{*}$ & Si(SexDaxSh) \\
\hline Residual & 216 & 104.59 & & 0.22 & & 0.41 & & \\
\hline Total & 287 & & & & & & & \\
\hline \multirow{2}{*}{$\begin{array}{l}\text { Transform } \\
\text { Cochran's Test }\end{array}$} & & \multicolumn{2}{|c|}{ none } & \multicolumn{2}{|c|}{$\operatorname{Ln}(\mathrm{X}+1)$} & \multicolumn{2}{|c|}{$\operatorname{Ln}(X+1)$} & \\
\hline & & $\mathrm{C}=0.0702$ & n.s. & $\mathrm{C}=0.0829$ & n.s. & $\mathrm{C}=0.0820$ & n.s. & \\
\hline
\end{tabular}

3

4 


\section{Table 2 (on next page)}

Significant differences for condition index and clump thickness of M. galloprovincialis at the different studied temporal and spatial scales.

Table 2. Summary of univariate analyses of variance (ANOVA) for condition index and clump thickness of M. galloprovincialis. Significant differences indicated in bold. s.: significant; n.s.: not significant, ${ }^{*} p<0.05^{* *} p<0.01{ }^{* * *} p<0.001$ 
2 Table 2. Summary of univariate analyses of variance (ANOVA) for condition index and clump thickness of M. galloprovincialis.

3 Significant differences indicated in bold. s.: significant; n.s.: not significant, ${ }^{*} \mathrm{p}<0.05^{* *} \mathrm{p}<0.01{ }^{* * *} \mathrm{p}<0.001$

\begin{tabular}{|c|c|c|c|c|c|c|}
\hline \multirow{2}{*}{ Source of variance } & \multirow{2}{*}{ df } & \multicolumn{2}{|c|}{ Condition Index } & \multicolumn{2}{|c|}{ Clump Thickness } & \multirow{2}{*}{ F versus } \\
\hline & & MS & $\mathbf{F}$ & MS & $\mathbf{F}$ & \\
\hline Season $=$ Se & 1 & 0.0028 & 0.12 & $\begin{array}{c}0.041 \\
3\end{array}$ & 0.03 & $\mathrm{Da}(\mathrm{Se})$ \\
\hline $\operatorname{Date}(\mathrm{Se})=\mathrm{Da}(\mathrm{Se})$ & 4 & 0.0232 & $18.40^{* * *}$ & $\begin{array}{c}1.472 \\
2\end{array}$ & $6.98^{* * *}$ & $\operatorname{Si}(\operatorname{SexDaxSh})$ \\
\hline Shore $=$ Sh & 5 & 0.0143 & 2.71* & $\begin{array}{c}2.606 \\
7\end{array}$ & $5.47^{* *}$ & $\mathrm{ShxDa}(\mathrm{Se})$ \\
\hline Site(SexDaxSh)=Si(SexDaxSh) & 36 & 0.0013 & 0.92 & $\begin{array}{c}0.210 \\
9\end{array}$ & $3.55^{* * *}$ & $\begin{array}{l}\mathrm{Pl}(\operatorname{SexDaxShxS} \\
\text { i) }\end{array}$ \\
\hline $\begin{array}{l}\operatorname{Plot}(\operatorname{SexDaxSh} x S i)=\operatorname{PI}(\operatorname{SexDaxSh} x \\
\text { Si) }\end{array}$ & 216 & 0.0014 & $3.28^{* * *}$ & $\begin{array}{c}0.059 \\
3\end{array}$ & $1.64^{* * *}$ & Residual \\
\hline SexSh & 5 & 0.0011 & 0.20 & $\begin{array}{c}0.222 \\
1\end{array}$ & 0.47 & $\mathrm{ShxDa}(\mathrm{Se})$ \\
\hline $\operatorname{ShxDa}(\mathrm{Se})$ & 20 & 0.0053 & $4.17^{* * *}$ & $\begin{array}{c}0.476 \\
7\end{array}$ & $2.26^{*}$ & $\operatorname{Si}(\operatorname{SexDaxSh})$ \\
\hline Residual & $\begin{array}{c}259 \\
2\end{array}$ & 0.0004 & & $\begin{array}{c}0.036 \\
2\end{array}$ & & \\
\hline Total & $\begin{array}{c}287 \\
9\end{array}$ & & & & & \\
\hline $\begin{array}{l}\text { Transformation } \\
\text { Cochran's Test }\end{array}$ & & $\mathrm{C}=0$ & ne & $\mathrm{C}=0$ & $\begin{array}{l}\mathrm{K}+1) \\
8\end{array}$ & \\
\hline
\end{tabular}




\section{Table 3 (on next page)}

Significant differences for different size classes of M. galloprovincialis at the different studied temporal and spatial scales.

Table 3. Summary of univariate analyses of variance (ANOVA) for different size classes of $M$. galloprovincialis. Significant differences indicated in bold. s.: significant; n.s.: not significant, ${ }^{*} \mathrm{p}<0.05^{* *} \mathrm{p}<0.01^{* * *} \mathrm{p}<0.001$ 
3 Table 3. Summary of univariate analyses of variance (ANOVA) for different size classes of M. galloprovincialis. Significant

4 differences indicated in bold. s.: significant; n.s.: not significant, ${ }^{*} \mathrm{p}<0.05{ }^{* *} \mathrm{p}<0.01{ }^{* * *} \mathrm{p}<0.001$

\begin{tabular}{|c|c|c|c|c|c|c|c|c|c|c|c|c|c|c|}
\hline \multirow{2}{*}{ Source of variation } & \multirow{2}{*}{ df } & \multicolumn{2}{|c|}{ Class 1} & \multicolumn{2}{|c|}{ Class 2} & \multicolumn{2}{|c|}{ Class 3} & \multicolumn{2}{|c|}{ Class 4} & \multicolumn{2}{|c|}{ Class 5} & \multicolumn{2}{|c|}{ Class 6} & \multirow{2}{*}{ F versus } \\
\hline & & MS & $\mathbf{F}$ & MS & $\mathbf{F}$ & MS & $\mathbf{F}$ & MS & $\mathbf{F}$ & MS & $\mathbf{F}$ & MS & $\mathbf{F}$ & \\
\hline Season $=\mathrm{Se}$ & 1 & 0.68 & 0.83 & 0.70 & 0.19 & 0.59 & 0.01 & 0.08 & 0.07 & 0.06 & 0.95 & 0.59 & 0.01 & $\mathrm{Da}(\mathrm{Se})$ \\
\hline $\operatorname{Date}(\mathrm{Se})=\mathrm{Da}(\mathrm{Se})$ & 4 & 0.82 & $9.79^{* * * *}$ & 3.75 & $10.16^{* * *}$ & 104.95 & $8.25^{* * * *}$ & 1.13 & 1.29 & 0.06 & 0.54 & 48.98 & $120.57^{* * *}$ & $\mathrm{Si}(\mathrm{SexDaxSh})$ \\
\hline Shore $=S h$ & 5 & 0.08 & 0.52 & 1.16 & 1.25 & 15.02 & 0.68 & 2.98 & 1.82 & 0.70 & 2.24 & 1.44 & 1.40 & $\mathrm{ShxDa}(\mathrm{Se})$ \\
\hline $\operatorname{Site}(\operatorname{Sh})=\operatorname{Si}(\operatorname{SexDaxSh})$ & 36 & 0.08 & 0.95 & 0.37 & $2.49^{* * *}$ & 12.72 & $1.65^{*}$ & 0.87 & $2.33^{* * *}$ & 0.11 & 0.85 & 0.41 & $2.45^{* * *}$ & Residual \\
\hline SexSh & 5 & 0.18 & 1.18 & 0.60 & 0.64 & 8.06 & 0.36 & 0.80 & 0.49 & 0.23 & 0.73 & 1.44 & 1.40 & $\mathrm{ShxDa}(\mathrm{Se})$ \\
\hline ShxDa(Se) & 20 & 0.15 & 1.84 & 0.93 & $2.53^{* *}$ & 22.25 & 1.75 & 1.64 & $1.88^{*}$ & 0.31 & $2.82^{* *}$ & 1.02 & $2.52^{* *}$ & $\mathrm{Si}(\mathrm{SexDaxSh})$ \\
\hline Residual & 216 & 0.09 & & 0.15 & & 7.69 & & 0.37 & & 0.13 & & 0.16 & & \\
\hline Total & 287 & & & & & & & & & & & & & \\
\hline \multirow{2}{*}{$\begin{array}{l}\text { Transformation } \\
\text { Cochran's Test }\end{array}$} & \multicolumn{3}{|c|}{ none } & \multicolumn{2}{|c|}{$\operatorname{Ln}(X+1)$} & \multicolumn{2}{|c|}{ none } & \multicolumn{2}{|c|}{$\operatorname{Ln}(X+1)$} & \multicolumn{2}{|c|}{$\operatorname{Ln}(\mathrm{X}+1)$} & \multicolumn{2}{|c|}{ none } & \\
\hline & & $\mathrm{C}=0.2500$ & s. & $\mathrm{C}=0.0622$ & n.s. & $\mathrm{C}=0.0584$ & n.s. & $\mathrm{C}=0.0636$ & n.s. & $\mathrm{C}=0.0761$ & n.s. & $\mathrm{C}=0.9161$ & s. & \\
\hline
\end{tabular}

5

6 


\section{Table 4 (on next page)}

Significant differences for sediment content of M. galloprovincialis clumps at the different studied temporal and spatial scales.

Table 4. Summary of univariate analyses of variance (ANOVA) for sediment content of $M$. galloprovincialis clumps. Significant differences indicated in bold. s.: significant; n.s.: not significant, ${ }^{*} p<0.05^{* *} p<0.01 * * * 0.001$ 
1 Table 4. Summary of univariate analyses of variance (ANOVA) for sediment content of M. galloprovincialis clumps. Significant 2 differences indicated in bold. s.: significant; n.s.: not significant, ${ }^{*} \mathrm{p}<0.05^{* *} \mathrm{p}<0.01^{* * *} \mathrm{p}<0.001$

\begin{tabular}{|c|c|c|c|c|c|c|c|c|c|c|c|c|c|c|}
\hline \multirow{2}{*}{ Source of variation } & \multirow{2}{*}{ df } & \multicolumn{2}{|c|}{$63 \mu \mathrm{m}$} & \multicolumn{2}{|c|}{$125 \mu \mathrm{m}$} & \multicolumn{2}{|c|}{$250 \mu \mathrm{m}$} & \multicolumn{2}{|c|}{$500 \mu \mathrm{m}$} & \multicolumn{2}{|c|}{$1000 \mu \mathrm{m}$} & \multicolumn{2}{|c|}{ Total } & \multirow{2}{*}{ F versus } \\
\hline & & MS & $\mathbf{F}$ & MS & $\mathbf{F}$ & MS & $\mathbf{F}$ & MS & $\mathbf{F}$ & MS & $\mathbf{F}$ & MS & $\mathbf{F}$ & \\
\hline Season $=\mathrm{Se}$ & 1 & 0.07 & 0.01 & 2.21 & 0.77 & 2.23 & 0.59 & 8.87 & 1.97 & 0.47 & 0.25 & 1.39 & 0.49 & $\mathrm{Da}(\mathrm{Se})$ \\
\hline Date $(\mathrm{Se})=\mathrm{Da}(\mathrm{Se})$ & 4 & 5.37 & $2.86^{*}$ & 2.86 & 2.50 & 3.80 & 1.41 & 4.50 & 2.03 & 1.90 & 1.31 & 2.84 & 1.49 & $\mathrm{Si}(\mathrm{SexDaxSh})$ \\
\hline Shore $=$ Sh & 5 & 14.11 & $5.28^{* *}$ & 5.04 & $2.86^{*}$ & 24.21 & $11.54^{* * *}$ & 22.94 & $6.28^{* * *}$ & 11.34 & $5.51^{* *}$ & 17.78 & $7.42^{* * *}$ & $\mathrm{ShxDa}(\mathrm{Se})$ \\
\hline $\operatorname{Site}(\operatorname{Sh})=\operatorname{Si}(\operatorname{SexDaxSh})$ & 36 & 1.88 & $2.22^{* * *}$ & 1.14 & $3.13^{* * *}$ & 1.99 & $3.05^{* * *}$ & 2.22 & $2.82^{* * *}$ & 1.45 & $3.80^{* * * *}$ & 1.90 & $3.68^{* * *}$ & Residual \\
\hline SexSh & 5 & 2.67 & 1.00 & 1.05 & 0.60 & 2.21 & 1.06 & 1.30 & 0.36 & 1.65 & 0.80 & 1.64 & 0.68 & ShxDa(Se) \\
\hline ShxDa(Se) & 20 & 2.67 & 1.42 & 1.76 & 1.54 & 2.10 & 1.05 & 3.66 & 1.65 & 2.06 & 1.41 & 2.40 & 1.26 & $\mathrm{Si}(\mathrm{SexDaxSh})$ \\
\hline Residual & 216 & 0.84 & & 0.36 & & 0.65 & & 0.79 & & 0.38 & & 0.52 & & \\
\hline Total & 287 & & & & & & & & & & & & & \\
\hline \multirow{2}{*}{\multicolumn{2}{|c|}{$\begin{array}{l}\text { Transformation } \\
\text { Cochran's Test }\end{array}$}} & \multicolumn{2}{|c|}{ none } & \multicolumn{2}{|c|}{$\operatorname{Ln}(X+1)$} & \multicolumn{2}{|c|}{$\operatorname{Ln}(X+1)$} & \multicolumn{2}{|c|}{$\operatorname{Ln}(X+1)$} & \multicolumn{2}{|c|}{$\operatorname{Ln}(X+1)$} & \multicolumn{2}{|c|}{$\operatorname{Ln}(X+1)$} & \\
\hline & & $\mathrm{C}=0.2446$ & S. & $\mathrm{C}=0.0789$ & n.s. & $\mathrm{C}=0.0564$ & n.s. & $\mathrm{C}=0.0691$ & n.s. & $\mathrm{C}=0.0521$ & n.s. & $\mathrm{C}=0.0590$ & n.s. & \\
\hline
\end{tabular}

3 
Figure 1

Studied Area

Figure 1 - Location of the 6 studied shores along the Atlantic coast of Northern Portugal 


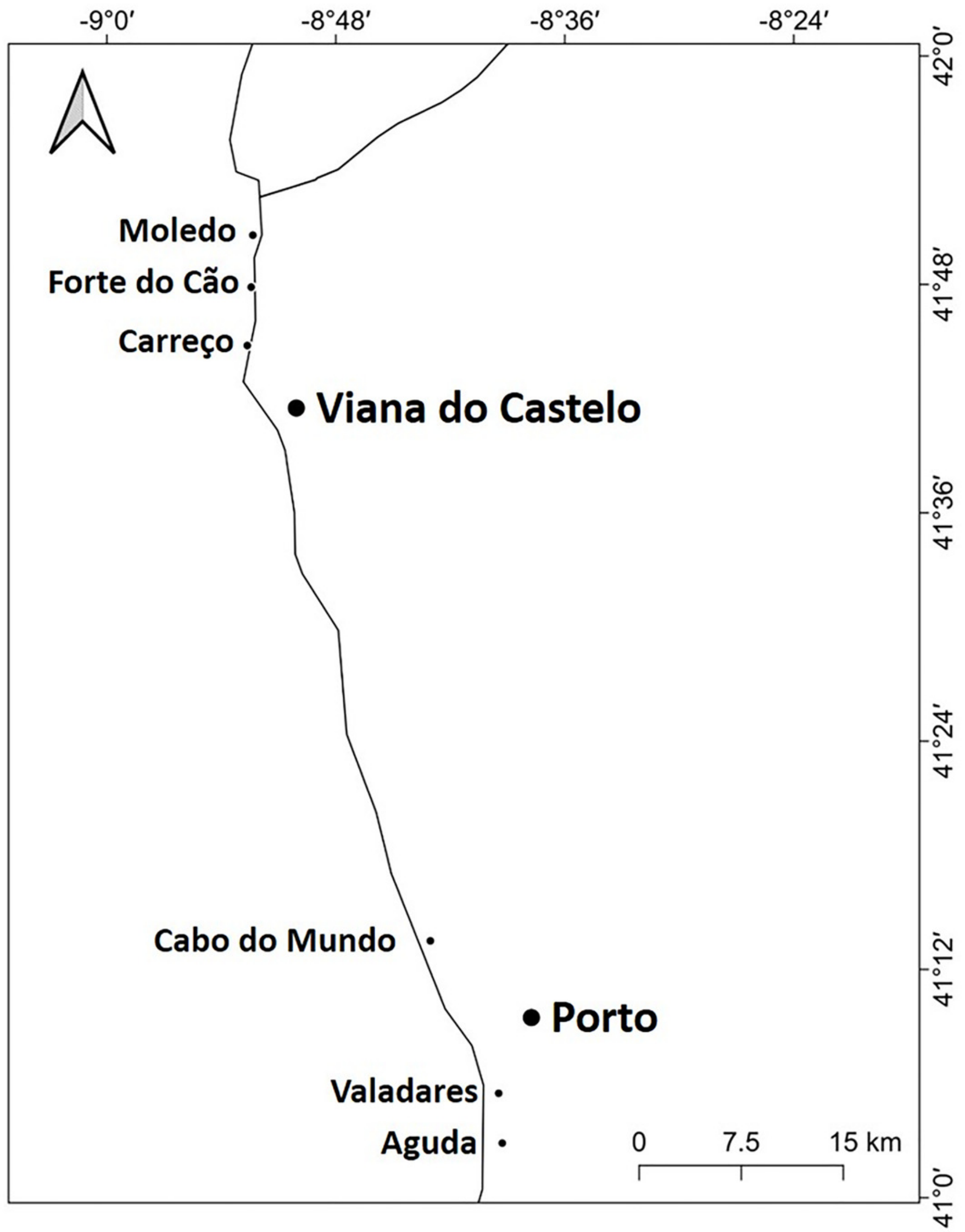




\section{Figure 2}

Environmental data

Figure 2 - Annual variability of environmental variables registered along the year at the studied area. (A) Temperature during 2019. Orange solid lines show the upper and lower limits of temperature tolerance for M. galloprovincialis. Blue solid lines show the upper and lower limits of optimal temperature for M. galloprovincialis. (B) Salinity during the year 2018. (C) Wave height during the year 2019. In all the figures dashed brown line represents maximum monthly values, black solid line represents average monthly values and dash and dot blue line represents minimum monthly values. 

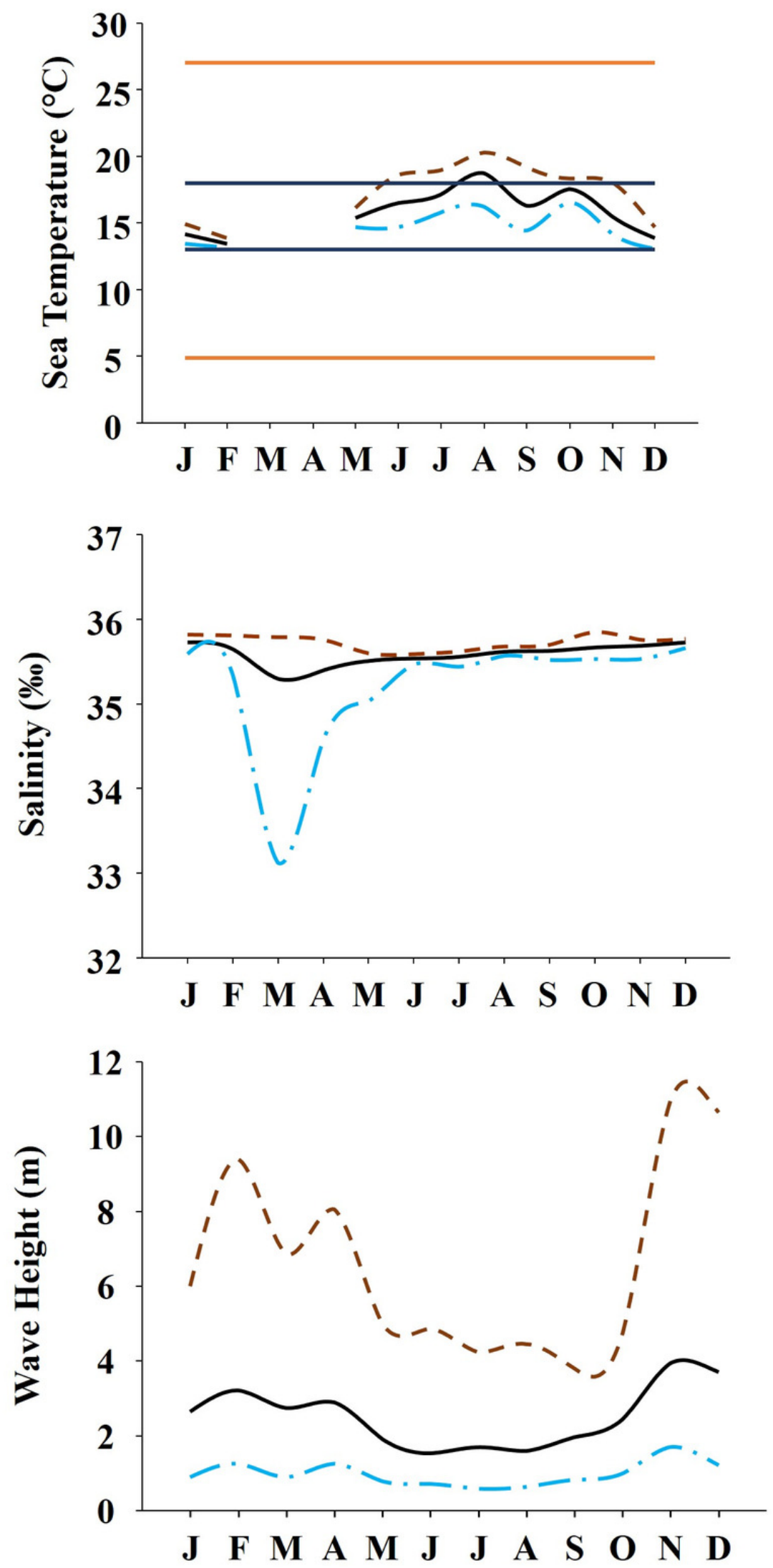

PeerJ reviewing PDF | (2020:08:52360:4:0:NEW 26 Apr 2021) 
Figure 3

Percentage cover of Mytilus galloprovincialis at different studied shores.

Figure 3 -Percentage cover of Mytilus galloprovincialis at different studied shores.

Mean values (+ SE) of percentage cover in $50 \times 50 \mathrm{~cm}$. 


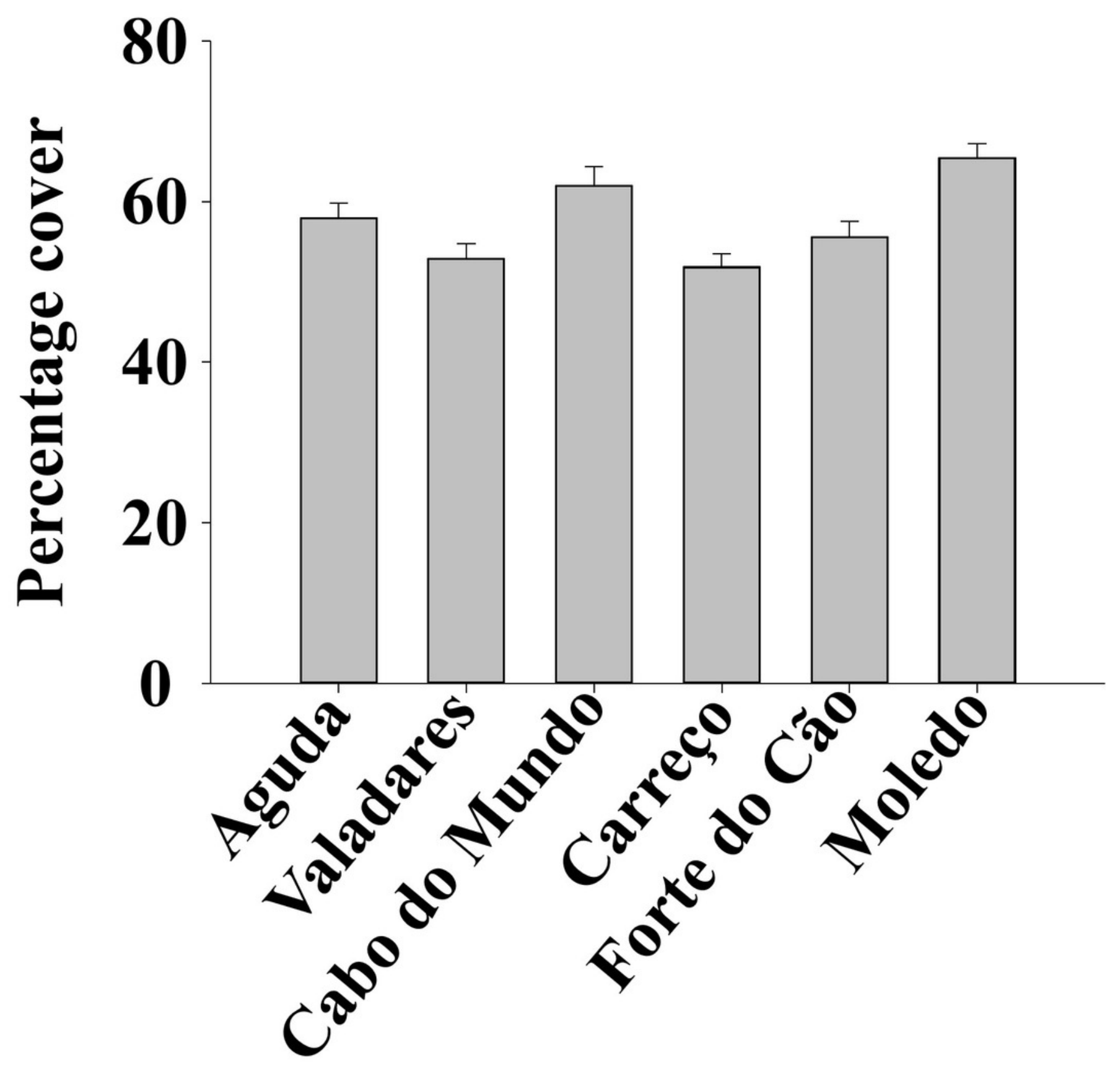


Figure 4

Significant differences of density of Mytilus galloprovincialis at different shores and dates.

Figure 4 - Density of Mytilus galloprovincialis at different shores and dates. Mean values (+ SE) of density (number of mussels per $10 \mathrm{~cm}^{2}$ ). Different letters indicate significant differences between shores $(P<0.01)$ as detected by SNK test.

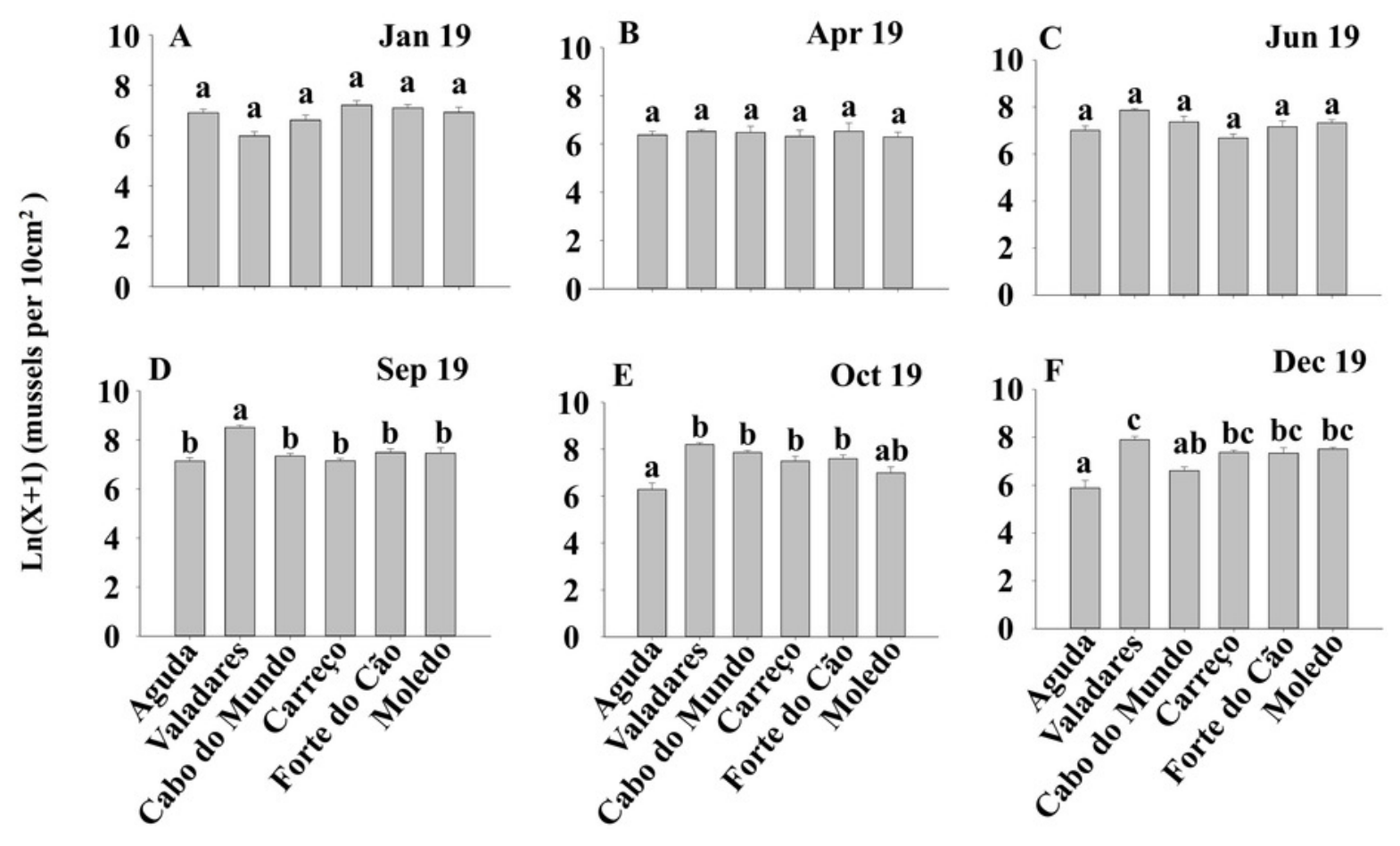


Figure 5

Density of Mytilus galloprovincialis in spat stage at different shores and dates.

Figure 5 - Density of Mytilus galloprovincialis in spat stage at different shores and dates. Mean values $(+\mathrm{SE})$ of mussels in spat stage (number of mussels with size between 500 and $1000 \mu \mathrm{m}$ per $10 \mathrm{~cm}^{2}$ ). Different letters indicate significant differences between shores $(\mathrm{P}<0.01)$ as detected by SNK test.

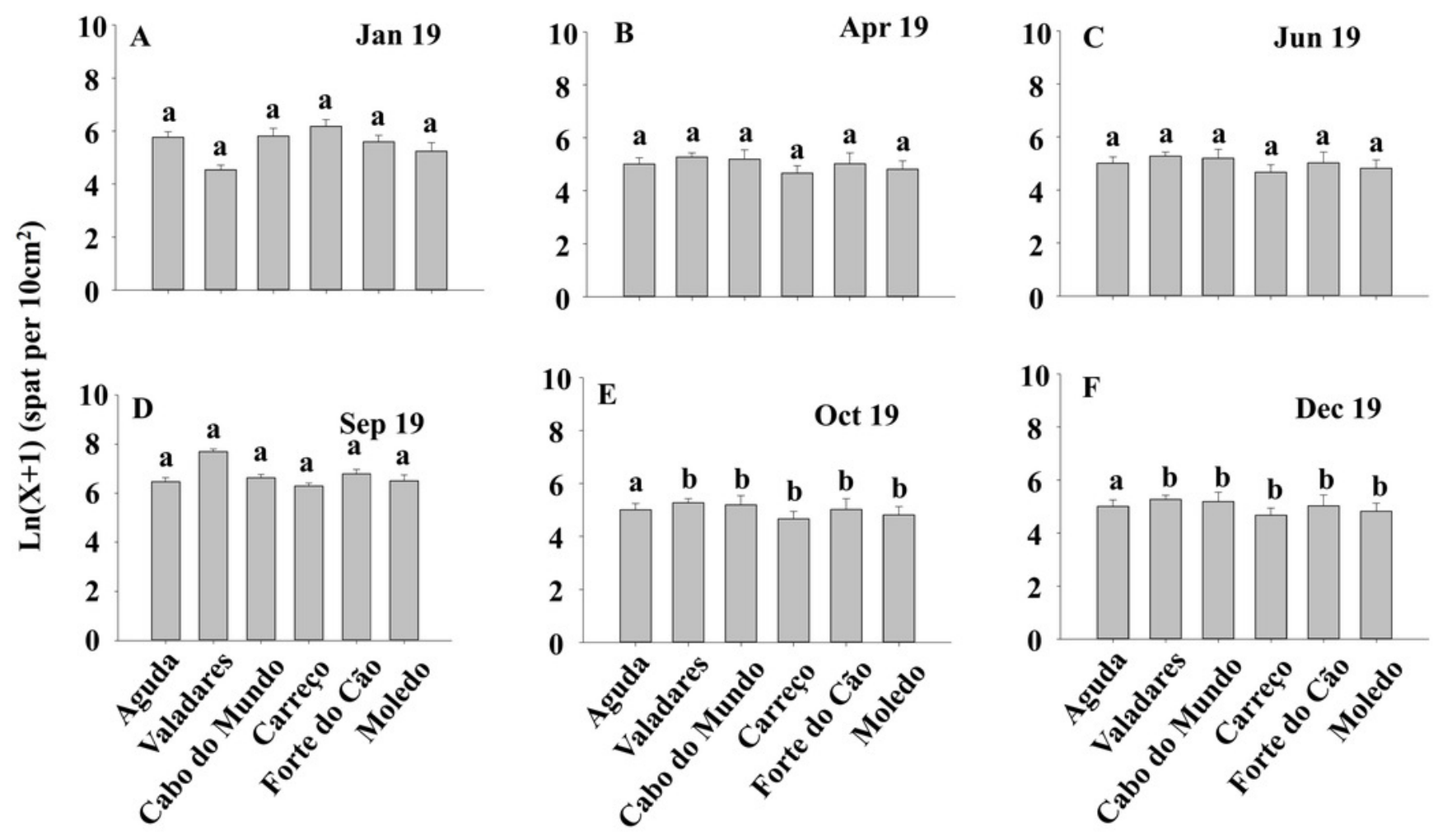


Figure 6

Condition index of Mytilus galloprovincialis at different shores and dates.

Figure 6 - Condition index of Mytilus galloprovincialis at different shores and dates.

Mean values (+ SE) of conditionindex. Different letters indicate significant differences between shores $(P<0.01)$ as detected by SNK test.

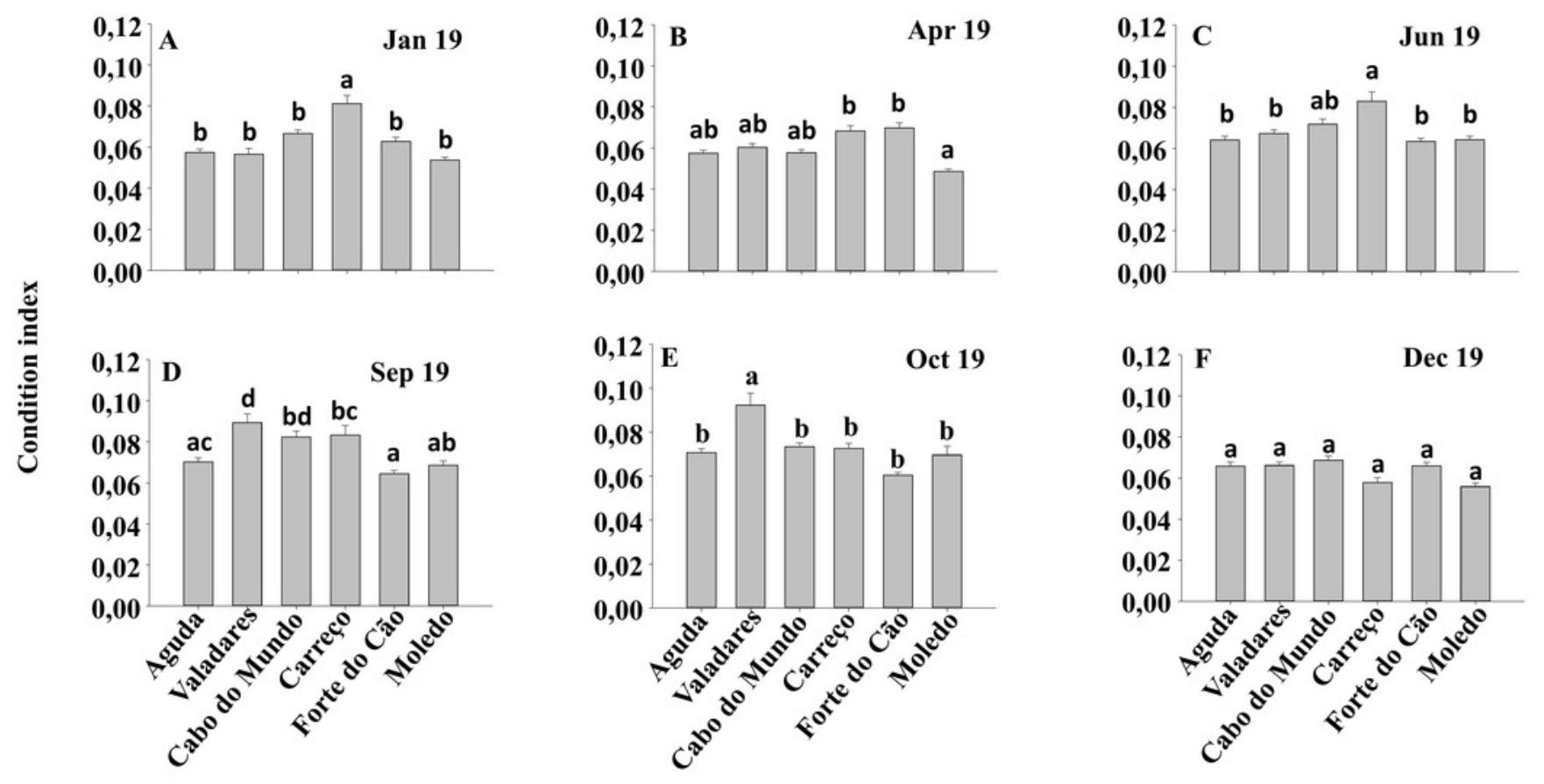


Figure 7

Clump thickness of Mytilus galloprovincialis at different shores and dates.

Figure 7 - Clump thickness of Mytilus galloprovincialis at different shores and dates.

Mean values (+ SE) of clump thickness in $\mathrm{cm}$. Different letters indicate significant differences between shores $(P<0.01)$ as detected by SNK test.
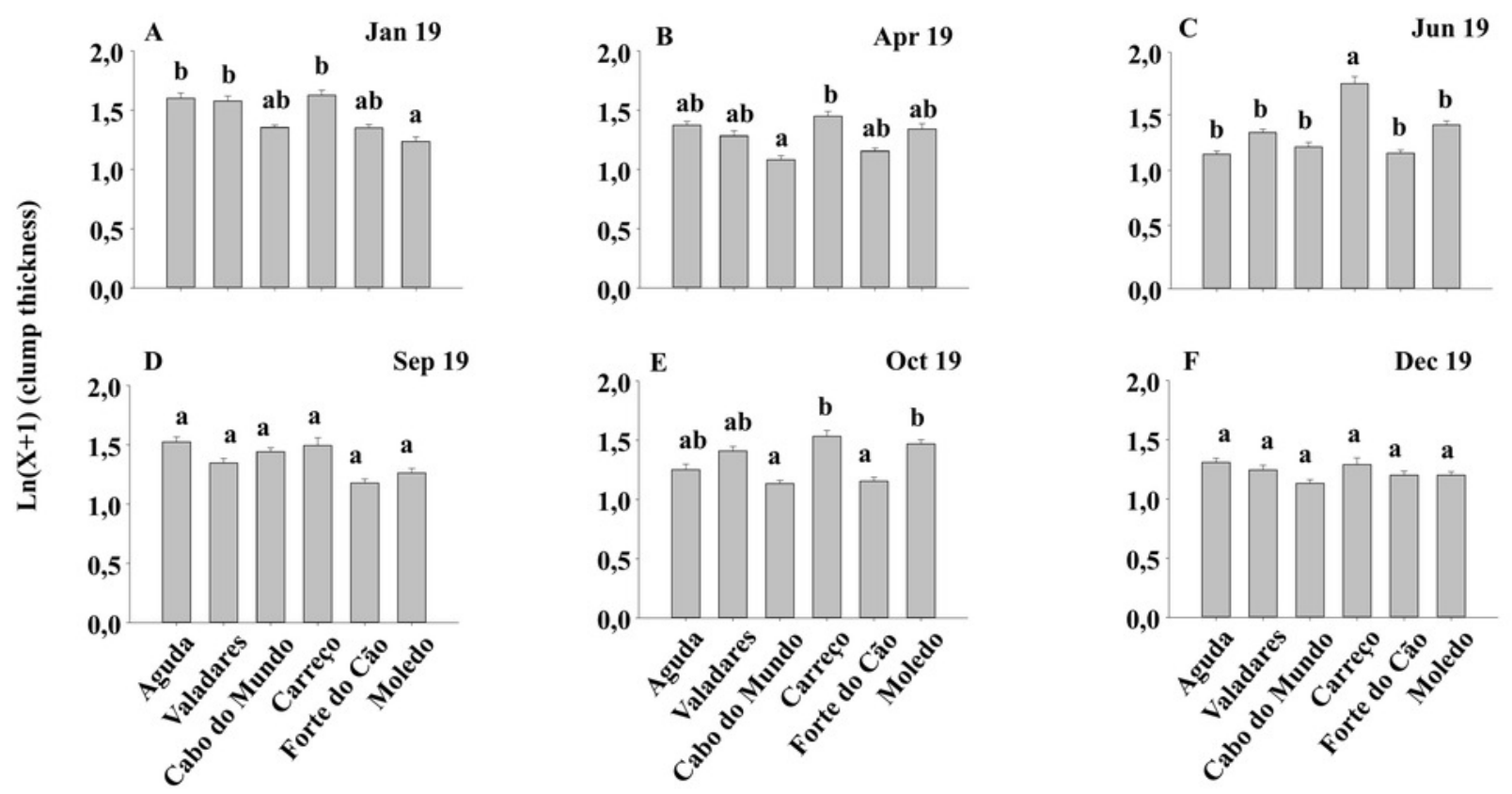
Figure 8

Sediment content of Mytilus galloprovincialis clumps at different shores

Figure 8 - Sediment content of Mytilus galloprovincialis clumps at different shores.

Mean values (+ SE) of sediment content in grams. Different letters indicate significant differences between shores $(P<0.01)$ as detected by SNK test.
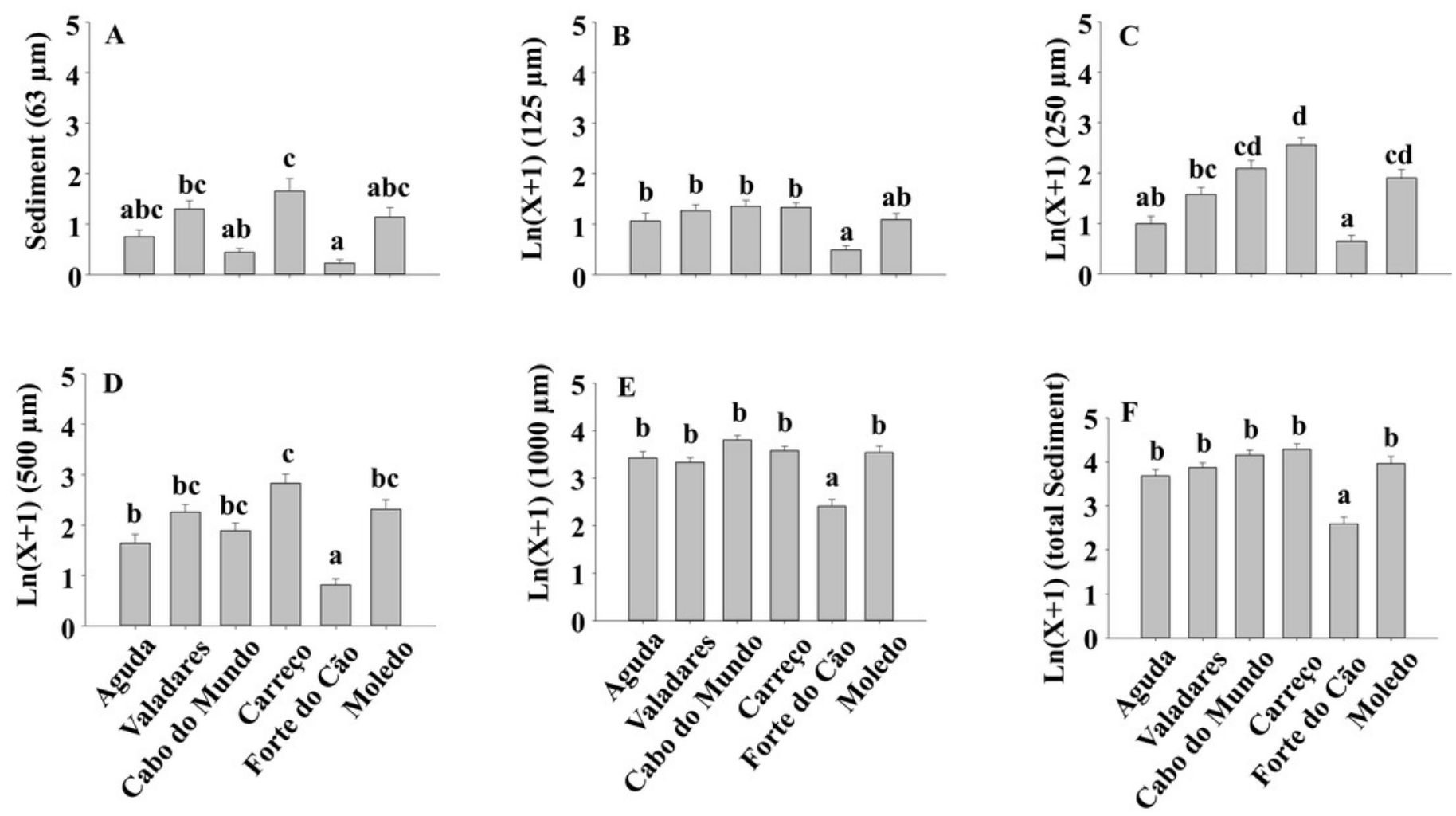